\section{Shelf Work}

Shelf Work in Libraries. By William $\mathrm{H}$. Jesse. Chicago, American Library Association, 1952. 68p. \$1.25.

"Shelf Work" is a comparatively new term in the librarian's glossary. The author of this book considers shelf work to be "the act of delivering a book when it is wanted, returning it to its assigned place when it is no longer needed, and seeing that it is properly cared for until it is wanted again." To accomplish these objectives, shelf, work administration is concerned with the arrangement of the book collection; special shelving problems such as oversized books; the housing and arrangement of non-book materials; "the exploitation of architectural and aesthetic possibilities of building areas in which readers are in direct contact with the books"; order and cleanliness in the stack areas of the library; shifting of books or moving of the book collection, when and if this is required; and inventory of the book stock. The qualifications of the shelf worker, his training and his supervision, are also discussed in this book.

In essence, here is an attempt to describe in a small volume the management of the library's book collection. The emphasis is on "adequate and efficient service to the library user." This is a practical manual for the supervisor of shelf work whether shelf work is his full-time or part-time responsibility, and he is told "what should be done, why, and how it may best be accomplished." It will offer the uninitiated stack supervisor a good guide to his work and responsibilities. If he follows the foot-note references, he will learn more about specific problems which arise in his work area. He might be better served in this respect if the author had included a selective bibliography. For the experienced shelf worker, here is a quick review which he will find up to date on tried practices and suggestive of new approaches to old problems.

It seems to this reviewer that it would be unfair to attempt to criticize this book in detail. One could debate, for example, the validity of the statement that "the shelf worker who pages books must have access to the shelf list, if he is to do his work speedily and efficiently." In one short paragraph the author simply does not have sufficient space to particularize this assertion or to discuss the test upon which it is based. Again, a current concern of librarians is the question of com- pact shelving or compact storage. Reference is made to some of the better known articles and books on the subject, but it is not treated in any detail and is not mentioned in the chapter of the book on stack management and shelving equipment. Other examples could be cited, but the point remains that either the book was produced under too limited a budget or it was projected only as an introduction to the subject. This is not to say the book is not worth reading. It is a good manual. But in these days of emphasis on sound management and personnel practices in libraries and the mechanization of clerical routines and procedures, librarians need and deserve a more thoroughgoing analysis and evaluation of their experiences with these problems, available equipment, suggested procedures, and other data which will help them operate their libraries more efficiently and effectively. The author of Shelf Work in Libraries can do this job as is 'made evident by this book. It is up to the American Library Association to encourage and sponsor the undertaking.John H. Ottemiller, Yale University Library.

\section{Punched Cards in Libraries}

Library Applications of Punched Cards: A Description of Mechanical Systems. By Ralph H. Parker. Chicago, American Library Association, 1952. 8op. \$2.75.

Librarians are generally aware of two kinds of punched cards. The more familiar type, because it has been more frequently adapted to library routines, is the card notched or slotted along the edges and adapted to hand sorting from file by use of a needle. The other type of punched card is for use in machines manufactured by International Business Machines and Remington Rand, Inc. This latter type is the subject of Ralph Parker's book-the card used to actuate machines for the arrangement and tabulation of a variety of data. (Another book by another author also appeared this year with similar title, but on the subject of the notched card sorted by needle. ${ }^{1}$ ) The study in hand was started some ten years ago. It was withheld from publication to await new developments in the manufacture of punched card machines, so that a more com-

1 McGaw, Howard F. Marginal Punched Cards in College and Research Libraries. Washington, D.C. The Scarecrow Press, I952. 218 p. 
plete study of the application of punched cards to library uses could be presented.

Librarians began writing about methods and machines used in the business world and applicable to library operations more than twenty years ago. Many of these early efforts were simple management studies of isolated uses of various types of mechanical equipment which, under a given set of circumstances, produced savings in time, money or effort in the pursuit of the library's daily business. The mechanical aids were in the main easily mastered devices and many came into general usage. Punched card tabulation was talked about, a few articles appeared on its possible adaptation to library procedures, but for the most part, it was not understood, considered too expensive, and left to its more common applications in business and government accounting and statistical work. Perhaps punched cards first aroused librarians' interest when, as the author writes in his preface, "Miss Marjorie Quigley, who is Librarian of the Montclair, New Jersey, Free Public Library, had the temerity to try so radically new an idea as automatic book-charging. ..."

Mr. Parker has taken the magic out of the punched card for the librarian. First he carefully describes the operation of punched card equipment, the two makes available in this country, their differences and limitations, and the basic equipment required. By avoiding technical details as much as possible, he successfully carries the reader through all library activities and discusses the application of punched cards to each one-order work, processing operations, borrower's records, circulation control and analysis, bibliographic and indexing services, personnel records, fiscal records and controls and the administration of punched card installations. More important, he concerns himself with a program of unified record control for the library. As he points out, "the greatest value of punched cards comes from their use in a coordinated program." The punched card is not presented as the panacea which will solve all library management problems. The suggested procedures, forms, and applications are not considered common to all library situations. Local needs, local procedures, must be evaluated before punched cards will work.

The author serves well the library administrator in helping him to understand punched card systems, and the various kinds of machines available, and in particular, to evaluate both of them in consideration of his local requirements and his local problems. A bibliography, a glossary and generous use of figures, tables, and charts are most helpful. The library administrator will also appreciate, as the author points out, that punched cards do not necessarily represent savings in themselves, but that through increased efficiency additional work can be accomplished and the administrator will have at his command data to help him do a more informed job in decision making, in the study of his use of funds, and in his efforts to control the book collection, to name a few examples. In this connection, Mr. Parker's projection of the organizational pattern of a library employing punched cards in all suggested applications and in a coordinated program offers stimulating reading.

Here then is a complete and careful examination of punched cards and punched card machines for libraries. It is a book for both the experienced and the inexperienced, and it should be read by all interested in library management problems and the mechanization of library clerical routines.-John H. Ottemiller, Yale University Library.

\section{General Education}

General Education in Action. . By B. Lamar Johnson. Washington, D.C., The American Council on Education, 1952. 409p. $\$ 4.00$.

Action, power and vision are the keynotes of General Education in Action, a Report of the California Study of General Education in the Junior College, written by Dr. B. Lamar Johnson of Stephens College, Columbia, Missouri, under the auspices of four educational organizations, and with the aid of a grant from the Carnegie Foundation for the Advancement of Teaching. Dr. Johnson is well known as the very able librarian and dean of instruction of one of the nation's outstanding junior colleges.

The four far-reaching organizations which sponsored this study are the California State Junior College Association, the California State Department of Education, the School of Education at the University of California at Los Angeles, and the Pacific Coast Committee of the American Council on Education. 